\title{
健診における $\mathrm{A}$ 型行動パターン評価の意義 ースクリーニングテストの作成一
}

\section{保坂 隆* 田川隆介** \\ 日野原茂雄*** 高橋為生}

\section{I . はじめに}

A 型行動パターンは虚血性心疾患の危険因子 として，また動脈硬化症の促進因子として近年わ が国でも注目されてきている(1)。A 型行動パター ンとは, 絶えず時間に追われた感じでイライラし やすい・食事のスピードが早い・人の話をゆっく り聞けず急がす傾向がある・職場や家庭で怒鳴る ことが多い・などの攻撃的・衝動的な面と, 昼食 後も休数せずにすぐ仕事に取りかかる・夜遅くま であるいは休日でも仕事に出掛ける・などの仕事 中心主義的な面を有する一連の行動パターン(2)を いう。また，これらとは正反対の行動パターンは B 型行動パターンと言われている。

諸外国では面接法や質問表などで評価されてい るが，わが国では筆者らの比較文化的な研究結 果(3)も含めて, 25 項目あるいは 36 項目の多肢選 択式の質問から成る「東海大式日常生活調查表(第 2 版)」などで評価できる。この質問表から行動パ ターン・スコアを算出する過程で各質問項目間の 「重みづけ」を考慮しているが, この重回帰係数の 高い項目すなわちスコア算出の際により影響を与 える質問項目 11 個を抽出して, 表一1のような 「A 型行動パターン・スクリーニングテスト」を作 成した。そして本スクリーニングテストを 1986 年 1 月より東海大学病院自動化健診センターにおい て, 全受診者に対して施行しているのでその結果

\section{Application of a Screening Test for Type A Behav-} ior Pattern at the Health Counselling Center

* 東海大学医学部精神科

** 同 内科

*** 東海大学病院健診センター

(1989 年 3 月 1 日受稿)
を報告し，健診センターにおける本テストの施行 意義について考察する。

\section{I. 方法}

本スクリーニングは表一1に示したようなマー クシート方式の質問表であり, 表一 2 に示したよ うな選択肢毎の点数により全体的な $\mathrm{A}$ 型行動パ ターン・スコアが算出できるようにプログラムさ れている。そして約 500 人を対象とした準備研 究(4)から, スコア分布が平均値 $43 \cdot 0$, 標準偏差 9.16 であることが判明しているため平均值およ び平均値士標準偏差の計 3 点で区切り, 高得点群 から便宜的に $\mathrm{A}_{1} \cdot \mathrm{A}_{2} \cdot \mathrm{B}_{2} \cdot \mathrm{B}_{1}$ の 4 群に分類評価し た。この場合は, $\mathrm{A}_{1}$ は極端な $\mathrm{A}$ 型行動パターン, $\mathrm{B}_{1}$ は極端な $\mathrm{B}$ 型行動パターンを意味している。実 際にはこの行動パターン評価は, 血圧・喫煙・肥 満などの虚血性心疾患やいわゆる成人病の危険因 子と共に, 受診者に示されている。

A 型行動パターンと他の危険因子との関係を 検討するための対象は, 1986 年 4 月〜 1987 年 3 月 (1 年間)の受診者 9749 名であり, A 型行動パター ンの再現性を検討するための対象は，それらのう ち 1987 年 4 月〜 9 月 (半年間) に再受診した 3347 名である。

\section{III. 結果}

まず 9749 名の全受診者（男性 7000 名, 女性 2749 名）の行動パターン別の内訳は $\mathrm{A}_{1}=1469$, $\mathrm{A}_{2}=4001, \mathrm{~B}_{2}=3462, \mathrm{~B}_{1}=817$ 名であった。

また従来, 当自動化健診センターにおいて受診 者に示されてきた危険因子は，契煙・飲酒・肥満・ 総コレステロール值・中性脂肪値・血圧・空腹時 血糖值・遺伝・運動習慣・尿酸値・身体活動など の 11 項目であった。行動パターンの 4 群のそれぞ 
健診におけるA型行動パターン評価の意義

表 $1 \mathrm{~A}$ 型行動パターン・スグリーニングテスト

1. ストレスや緊張したとき上腹部が涌むことがありますか

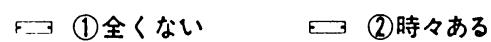
・ッ (3)しばしばある

2. あなたの気性は激しい方ですか

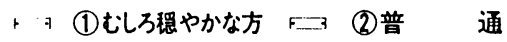

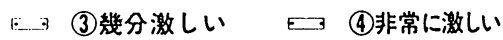

3. あな大情任感が強いと人から言われたことがありますか (1)全くない 曰 (2)時々いわれた 曰(3)しばしばいわれた 口（4)いつもいわた

4. あなたは仕事に対して自信をもっていますか Fヨ（1)全くない せ（2)あまりない

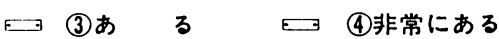

5. 仕事を早くはかとらせるために特別に早起き して職場に行くことがありますか ๒ (1)全くない も (2)あまりない モ (3)しばしばある (4)非常にある

6. 約束の時間には遅れる方ですか

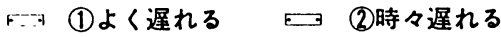
○（3)決して遅れない モ（4)30分前には必行く
7. 自分が正しいと思うことはとこまでも貫くことがありますか

$$
\begin{aligned}
& \text { (1)全くない 尔）時々ある } \\
& \text { (3)しばしばある (4)常にある }
\end{aligned}
$$

8. 数日間の観光旅行をすると仮定した場合

$$
\begin{aligned}
& \rightleftarrows \text { (1)特に計画はたてず、成り行きまかせで行く } \\
& 己 \text { (2)1日単位で大体の計画をたてる } \\
& \rightleftarrows \text { (3)時間単位で細かく計画をたてる }
\end{aligned}
$$

9. 他人から指図された時あなたはどう思いますか せ(1)気が楽だと思う ๒（2)気にとめない も（3)嫌な気がする (4)怒りを覚える

10. あなたが車を運転していたと仮定し、後の車に追 い越されたとしたらあなたはどうますか

๒ (1)マイベースで走り緻ける

๒（2スピードを上げなるへく追い越し返方うと思う

11. 仕事が終わって閫宅したらリラックスした気分になれますか

๒ (1)すぐになれる

曰（2)すくにはなれないが、比故的早くリラックスできる

も(3)少しイライラした気持ちが続く

๒ (4)イライラして家族にヘッ当りすることが多い

行動パターンの判定

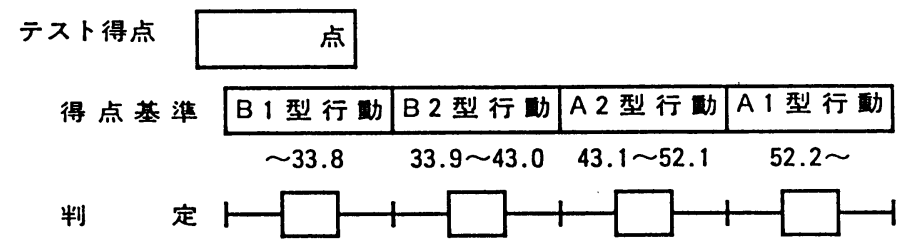

れにおける各危険因子を有する (各危険因子は 1 ・ $2 \cdot 3 \cdot 4$ の 4 段階一一例えば, 喫煙における評価は, $1: 0$ 本, $2: 1$ 日 10 本以下, $3: 1$ 日 11 20 本, $4:$ 1 日 20 本以上一に評価されているが,「危険因 子を有する」とは 3 および 4 と評価された場合を 言う)割合を図一1に示す。それによれば, 行動パ ターン・スコアが上昇するに伴い，危険因子を有 する割合が増すのは喫煙・飲酒・肥満・総コレス テロール値・中性脂肪值・血圧・空腹時血糖值な どの 7 項目であった。

さらに, 当自動化健診センターにおいて実施さ
れた心電図所見と上部消化管造影所見にて「異常 所見」および「精検を要する」と評価された者の 割合を，行動パターン別に示したのが図一2であ る。それによれば, A 型行動パターンを呈するほ ど陳旧性心筋梗塞と上部消化管造影による異常所 見の比率が高くなることがわかる。

最後に, 約 1 年間を経て再受診した者 3347 名に ついての行動パターン評価の推移を表一 3 に示 す。これによれば，4段階の区分について，隣り合 うた群への推移を認めた場合には, その再現性は きわめて高いことがわかる。 
日本総合健診医学会誌

表 2 A 型行動パターン・スコア算出法

\begin{tabular}{|c|c|c|c|c|c|c|}
\hline 質問項目 & 選択肢 & 즈 コ & 質問項目 & 選択肢 & 즈 & $\beth$ \\
\hline \multirow[t]{4}{*}{1} & (1) & 0.0900 & 7 & (1) & 0 . & 1027 \\
\hline & (2) & 0.2236 & & (2) & 0 . & 2573 \\
\hline & (3) & 0.3312 & & (3) & 0 . & 3703 \\
\hline & & & & (1) & 0. & 4765 \\
\hline \multirow[t]{4}{*}{2} & (1) & 0.0639 & & & & \\
\hline & (2) & 0.1455 & 8 & (1) & -0 . & 1516 \\
\hline & (3) & 0.2147 & & (2) & -0 . & 3775 \\
\hline & (4) & 0.2799 & & (3) & -0 . & 6091 \\
\hline \multirow[t]{4}{*}{3} & (1) & -0.0609 & 9 & (1) & 0 . & 0565 \\
\hline & (2) & -0.1365 & & (2) & 0 . & 1257 \\
\hline & (3) & -0.1913 & & (3) & 0 . & 1943 \\
\hline & (4) & -0.2456 & & (4) & 0 . & 2727 \\
\hline \multirow[t]{5}{*}{4} & (1) & 0.1090 & 10 & (1) & 0 . & 2372 \\
\hline & (2) & 0.2124 & & (2) & 0 . & 4744 \\
\hline & (3) & 0.3351 & & & & \\
\hline & (4) & 0.4807 & 11 & (1) & 0 . & 1198 \\
\hline & & & & (2) & 0 . & 2806 \\
\hline \multirow[t]{4}{*}{5} & (1) & 0.0736 & & (3) & 0 . & 4072 \\
\hline & (2) & 0.1649 & & (4) & 0 . & 5220 \\
\hline & (3) & 0.2324 & & & & \\
\hline & (4) & 0.2933 & & & & \\
\hline \multirow[t]{4}{*}{6} & (1) & 0.2516 & & & & \\
\hline & (2) & 0.6033 & & & & \\
\hline & (3) & 0.9334 & & & & \\
\hline & (4) & 1. 2824 & & & & \\
\hline
\end{tabular}

A 型行動パターン・スコア＝（選択肢に相当する得点の合計一0. $2387 ） \times 25$

\section{IV. 考察}

本スクリーニングテストは数分間で記入可能で あり，そのスコア算出法も比較的単純である。そ れに加えて, 本研究から得られた結果は, 臨床的 にも予防医学的にも非常に興味深いものであると 思われる。

まず，A 型行動パターンを呈するほど従来の虚 血性心疾患・成人病の危険因子を有する割合が高
いことが明らかにされた。A 型行動パターンとは ある意味では, 仕事中心主義的な現代人の行動を 象徵的に表わしていると言える。すなわち，時間 に追われ夜遅くまで働き続けるといった行動パ夕 一ンは, 実は現代社会や企業が期待する姿であり, そのような期待に過剰適応するためには, 必然的 にA 型行動パターン的に行動することを余儀な くされているわけである。そして，そのような A 型行動パターン的人間がストレスを回避したり発 

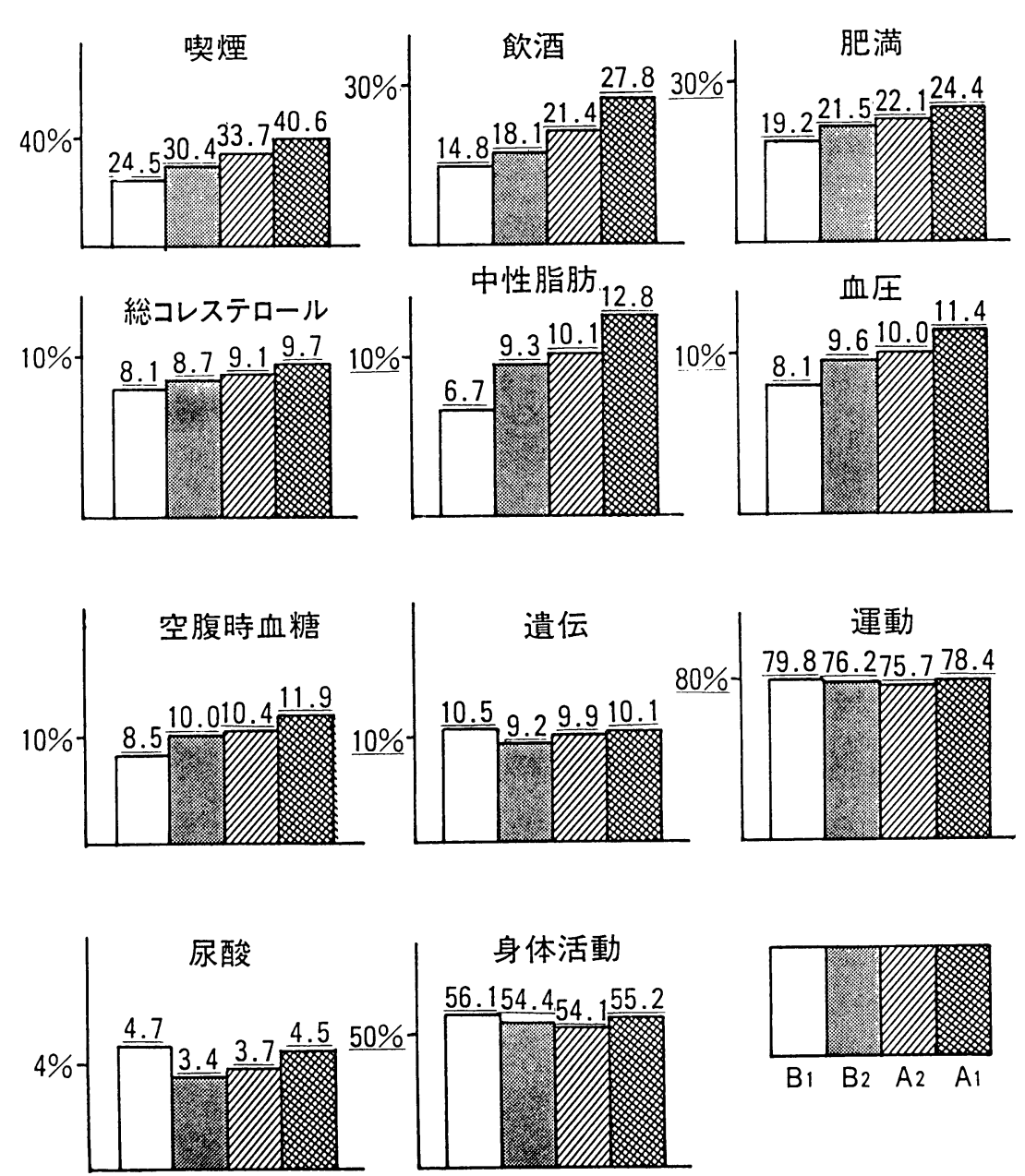

図 1 行動パターンによる危険因子の比較

(\%: 中等度以上の值を有する受診者の比率)

散したりする際に, 鿄煙したり飲酒したり ${ }^{(5)}$, 結果 的に肥満や高脂血症に至っているのではないかと いう推測が容易にできる。一方このような単純な 推測とは別に, A 型行動パターンは従来の危険因 子とは独立していることが諸外国 ${ }^{(6)}$ でもわが国(7) でも確かめられているが, 本研究の中でも, 厳密 に言えば,その間に有意な相関は得られていない。 しかし,いずれにしても健診センターにおいては, 禁煙や禁酒を奨めることに加えて，ストレスへの 適応パターンについても指導することが望ましい と思われる。
次にA 型行動パターンは虚血性心疾患の危険 因子として知られているが, 本研究でも従来の説 に一致して，A 型行動パターンを呈するほど陳旧 性心筋梗塞が多いことが確かめられた。そしてそ れに加えて, A 型行動パターンは上部消化管造影 による「要再検率」とも関連することが明らかに なった。この知見は諸外国では報告されていない ものであり, A 型行動パターンの日本的特性を十 分示唆するものではあるが, 本研究では実際に再 検結果まで追跡していないため, 現時点ではたと えば「A 型行動パターンと消化性潰瘍とは関係が 

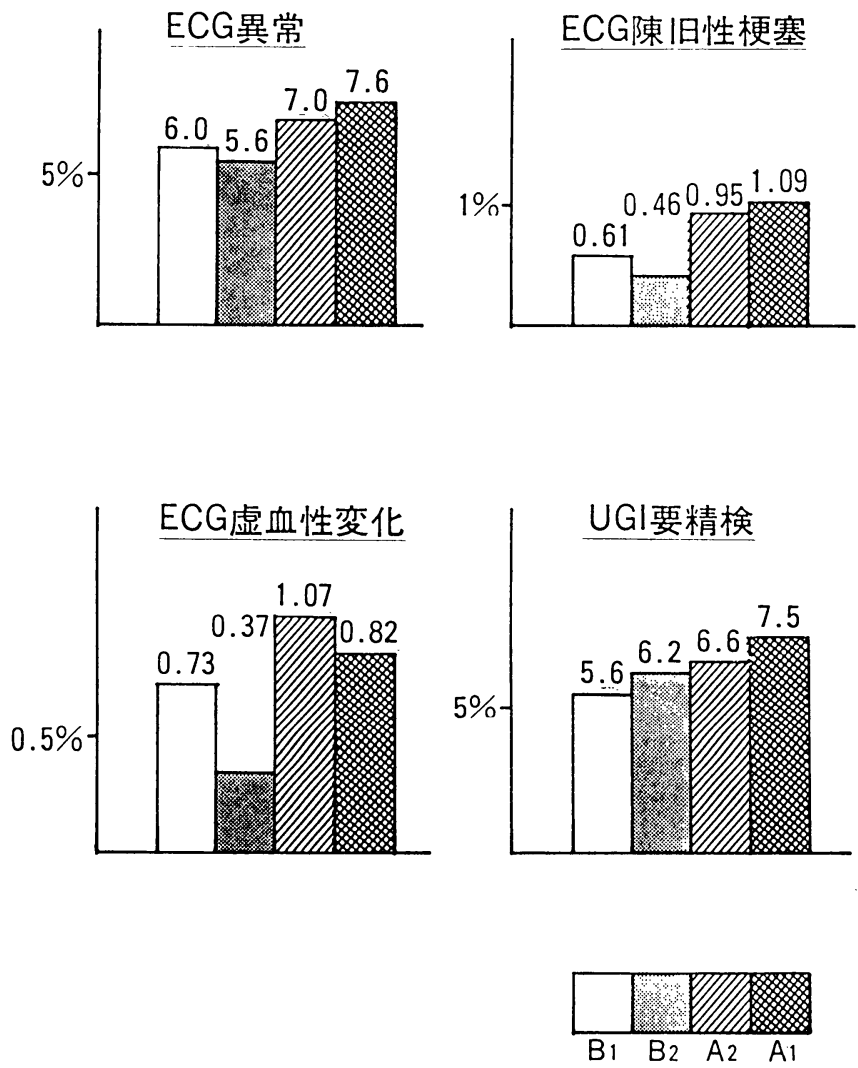

図2 行動パターンによる心電図所見と上部消化管造影所見

表 3 A 型行動パターンの変化 前回受診時

再受診時

$$
\begin{aligned}
& A_{1}: \text { 476名 } \longrightarrow\left\{\begin{array}{lr}
A_{1}: 203 \\
A_{2}: 221 \\
B_{2}: & 49 \\
B_{1}: & 3
\end{array}\right. \\
& A_{2}: 1418 \text { 名 } \longrightarrow\left\{\begin{array}{lr}
A_{1}: 198 \\
A_{2}: 756 \\
B_{2}: 422 \\
B_{1}: & 42
\end{array}\right. \\
& B_{2}: 1167 \text { 名 } \longrightarrow\left\{\begin{array}{lr}
A_{1}: 55 \\
A_{2}: 396 \\
B_{2}: 587 \\
B_{1}: 129
\end{array}\right. \\
& B_{1}: 286 \text { 名 } \longrightarrow\left\{\begin{array}{lr}
A_{1}: & 3 \\
A_{2}: & 39 \\
B_{2}: & 128 \\
B_{1}: & 116
\end{array}\right.
\end{aligned}
$$

ある」という単純な結論は出せないと思われる。 いずれにしても，A 型行動パターンの疾患特異性 については，文化的な背景を踏まえた今後の研究 が期待される。

さらに，再現性を検討した結果からは，A 型行 動パターンは修正され得るものであることと同時 に，特別な治療的介入をしなければ極端な変化は しないことも明らかになった。この一見矛盾する 結論は, 本研究が行なわれた時点では, A 型行動 パターンに対する介入の仕方が統一されていなか ったことに起因している。すなわち A 型行動パ夕 ーンは，仕事の内容や職種および過程状況などの 変化により自然に修正されていくことが確かめら れたのと同時に，そのような受動的変化には限界 があり，たとえば極端な $\mathrm{A}$ 型が極端な $\mathrm{B}$ 型に変 わるほどの影響は与えないことを意味している。 この点では，A 型行動パターンに対する積極的介 入により虚血性心疾患の再発率が低下したごとが 


\section{健診におけるA型行動パターン評価の意義}

米国で最近報告され(8)，わが国でもその治療的介 入についての研究が望まれる時期にきているとい える。

最後に，米国では厳密なプロスペクティブ・ス タディにより, A 型行動パターンは B 型行動パタ ーンに比べて約 2 倍の虚血性心疾患の発症が確か められた後に, A 型行動パターンの臨床的意義が 検討され始めたという経緯がある。その意味では, わが国のこれまでの研究はあくまでもレトロスぺ クティブなものであり, 本研究の対象は, A 型行 動パターンに関する本邦初のプロスペクティブ・ スタディになり得ること(9)も付記しておく。

\section{V. おわりに}

最近はわが国でも健康に対する関心が高まり， 今後, 健診センターが担う予防医学的役割はます ます重視されていくと思われる。そのため，身体 的な面での検查の精度や迅速性については次々に 改良されてきている。また一方で，健診センター には精神衛生的な面での役割も期待されてきてい るため, 各施設でも従来の身体的検査に加えて, 心理テストなどが導入され受診者に指導されてき ている。

本稿で述べた A 型行動パターンは, 精神的要素 と身体的状況を結びつけている新しい複合概念で あり，本スクリーニング・テストは簡略な手順に 比しきわめて重要な情報が得られるものである。 そのため本稿では，まだ使用して間もない本テス
トの臨床的意義と有用性などについて報告し，さ らに予防医学的意義についても述べた。

(本稿の要旨の一部は第 16 回日本総合健診医学 会総会にて発表した）

\section{[文献 $]$}

1）保坂 隆：行動パターンと老年者の虚血性心疾 患。老年医学, vol. 20, 2038-2046, 1982

2）保坂 隆：ストレス・A 型行動パターン。臨床栄 養, vol. 65, 685-688, 1984

3) Hosaka, T. \& Tagawa,R. : The Japanese Characteristic of Type A Behavior Pattern Tokai J Exp Clin Med. vol. 12, 287-303, 1987

4）保坂 隆, 田川隆介, 大枝泰彰, 五島雄一郎：A 型 行動パターンと虚血性心疾患一質問表の作成。心 身医学, vol. 24, 23-30, 1984

5）保坂 隆, 狩野力八郎：ストレスとアルコール。 心と体の健康事典，114-117，毎日新聞社，東京， 1988

6) The Review Panel on Coronary-prone Behavior and Coronary Heart Disease : A Critical Review. Circulation vol. 63, 1199-1215, 1981

7）大枝泰彰, 保坂 隆, 田川隆介, 五島雄一郎：A 型 行動パターンと虚血性心疾患一他の coronary risk factor との関係。心身医学, vol. 24, 125-132, 1984

8) Friedman, M. Thoresen, C., Gill, J. et al. : Alteration of type $\mathrm{A}$ behavior and reduction in cardiac recurrences in postmyocardial infarction patients. Am Heart J. vol. 108, 237-248, 1984

9) 保坂 隆：A 型行動パターン。医学のあゆみ, 147, 166-168, 1988 